\title{
STUDI KARAKTERISASI KITOSAN DARI CANGKANG KEPITING BAKAU (SCYLLA OLIVACEA) SEBAGAI PENJERNIH AIR PADA AIR SUMUR
}

\section{STUDY OF CHITOSAN CHARACTERIZATION FROM THE BAKAU CRAB SHELLS (SCYLLA OLIVACEA) AS PURIFICATION WATER FOR WELL WATER}

\author{
Thrysantia Angelin Pala'langan ${ }^{\star 1}$, Sinardi ${ }^{2}$, A.Sry Iryani $^{2}$ \\ 1,2Program Studi Teknik Kimia, Fakultas Teknik, Universitas Fajar, \\ Jln. Prof Abdurrahman Basalamah No. 101 Makassar, 90231 \\ *Email: santyaangelina@gmail.com
}

\begin{abstract}
ABSTRAK
Ketersediaan limbah kepiting bakau memiliki potensi yang sangat besar untuk dijadikan sebagai bahan baku pembuatan kitosan. Kitosan merupakan senyawa polimer multifungsi, karena mengandung 3 jenis asam amino, gugus hidroksi primer dan sekunder. Analisis penelitian berupa karakterisasi kitosan dan dosis penambahan kitosan ke dalam sampel air sumur serta waktu kontak kitosan di dalam sampel air. Proses ini melalui 3 tahapan, yaitu proses deproteinasi (proses penghilangan kandungan protein), proses demineralisasi (proses penghilangan kandungan mineral), dan proses deasetilasi (proses pembentukan kitin menjadi kitosan). Hasil karakterisasi kitosan sebagai berikut: memiliki tekstur serbuk bewarna putih kekuningan, tidak berbau, memiliki kadar air 3,46\%, kadar abu $1,00 \%$, dan derajat deasetilasi sebesar $73 \%$. Air sumur sebelum perlakuan dan sesudah penambahan kitosan dilakukan analisis untuk mengetahui terjadi perubahan. Sasaran uji yang dilakukan adalah uji pH dan uji kekeruhan. Pada analisis $\mathrm{pH}$ pada air sumur dihasilkan persentase kenaikan pH sebesar 1,56\% - 17,19\%. Pada pengujian kekeruhan air sumur mengalami penurunan nilai kekeruhan sebesar 78\% - 97\%. Hasil air sumur setelah penambahan kitosan terjadi perubahan nilai parameter sehingga memenuhi standar air menurut Menteri Kesehatan RI. Melalui penelitian ini, diketahui bahwa kitosan memiliki efektifitas yang tinggi sebagai adsorben untuk menjernihkan air.
\end{abstract}

Kata Kunci: adsorben , cangkang kepiting , kitosan

\section{ABSTRACT}

The availability of bakau crab shells has a huge potential to serve as a raw material for making chitosan. Chitosan is a multifunctional polymer compound, because it contains 3 types of amino acids, primary and secondary hydroxy groups. The research analyzes were chitosan characterization and dosage of chitosan addition into well water sample and chitosan contact time in water sample. This process through 3 stages, namely the process of deproteinasi (process of elimination of protein content), demineralization process (process of elimination of mineral content), and deacetylation process (chitin formation process into chitosan). Well water before treatment and after addition of chitosan analysis to know the happening of change. The test target is $\mathrm{pH}$ and turbidity test. Well water supply after chitosan addition changes parameter values to meet the water standard according to the Minister of Health Rl. Through this research, it is known that chitosan has a high effectiveness as an adsorbent to purify water.

Keywords: adsorbent , crab shells, chitosan 


\section{PENDAHULUAN}

Air merupakan kebutuhan yang sangat vital bagi kehidupan manusia. Karena itu, jika kebutuhan akan air tersebut belum tercukupi maka dapat memberikan dampak yang besar terhadap kerawanan kesehatan maupun sosial. Pengadaan air bersih di Indonesia khususnya untuk skala yang besar masih terpusat di daerah perkotaan, dan dikelola oleh Perusahan Air Minum (PAM) kota yang bersangkutan. Untuk daerah yang belum mendapatkan pelayanan air bersih dari PAM umumnya mereka menggunakan air tanah (sumur), air sungai, air hujan, air sumber (mata air) dan lainnya. Permasalahan yang timbul yakni sering dijumpai bahwa kualitas air tanah yang digunakan masyarakat kurang memenuhi syarat sebagai air bersih. Untuk mengatasi masalah tersebut, kitosan sebagai adsorben dapat menurunkan kekeruhan dan menurunkan partikel anorganik maupun organik yang tersuspensi dalam air sumur.

Pengolahan kepiting merupakan kegiatan pengolahan yang cukup banyak menghasilkan limbah. Limbah cangkang kepiting merupakan masalah yang perlu dicari pemecahannya. Salah satu pemanfaatan limbah cangkang kepiting tersebut adalah pengolahan menjadi kitosan. Cangkang kepiting yang mengandung senyawa kimia kitin dan kitosan merupakan limbah yang mudah didapat dan tersedia dalam jumlah yang banyak, yang selama ini belum termanfaatkan secara optimal. Kitosan yang diisolasi dari cangkang kepiting dapat digunakan sebagai adsorben. Gugus $-\mathrm{NH}_{2}$ mempunyai sepasang elektron bebas, itu berarti mempunyai sifat basa atau dalam larutan (air) akan meningkatkan $\mathrm{pH}$ sistem. Peningkatan $\mathrm{pH}$ sistem tentu saja dapat mengubah sifat asam basa permukaan yang berarti juga akan mempengaruhi kekuatan ikatan atau selektifitas pengikatan ion logam (Endang Widjajanti, 2003: 51 dalam Endoraza dkk, 2012). Kitosan memiliki dua gugus aktif yaitu $\mathrm{NH}_{2}$ dan $-\mathrm{OH}$ pada $\mathrm{pH}$ tertentu kedua gugus aktif ini dapat saja mengalami protonasi ataupun deprotonasi yang mestinya akan menghasilkan muatan permukaan yang berbeda.

Berdasarkan uraian tersebut dilakukan penelitian pemanfaatan limbah cangkang kepiting menjadi kitosan sebagai penjernih air pada air sumur.

\section{METODE PENELITIAN}

Cangkang Kepiting Bakau (Scylla olivacea) diperoleh dari pasar ikan Paotere Makassar. Digunakan sebanyak 30 gr dengan ukuran 40 mesh.

\section{Bahan}

Bahan yang digunakan untuk membuat kitosan yaitu serbuk cangkang kepiting, $\mathrm{NaOH} 3,5 \%, \mathrm{HCl} 15 \%, \mathrm{NaOH} 60 \%$, dan aquadest. Sedangkan bahan yang digunakan untuk proses penjernihan air yaitu air sumur dan kitosan. 


\section{Peralatan}

Alat yang digunakan untuk membuat kitosan yaitu neraca digital, termometer, gelas kimia $500 \mathrm{ml}$, spatula, mortar, corong, ayakan 40 mesh, kaca arloji, hot plate, magnetic stirer, erlenmeyer, kertas saring, stir, dan klem. Sedangkan alat yang digunakan dalam proses pengaplikasian kitosan sebagai penjernihan air yaitu botol plastik, gelas ukur, pH-meter, dan turbidimeter.

\section{Prosedur}

Penelitian ini dilakukan dalam beberapa tahap, yaitu persiapan bahan baku yaitu limbah cangkang kepiting bakau, proses pembuatan kitosan, proses analisis karakterisasi kitosan, dan proses pengaplikasian kitosan sebagai penjernih air sumur.

\section{Persiapan Bahan Baku}

Bahan baku cangkang kepiting bakau dicuci sampai bersih, kemudian dikeringkan dengan sinar matahari. Selanjutnya cangkang kepiting bakau dihaluskan/ digiling dan diayak dengan ukuran 40 mesh, hasil yang berupa serbuk cangkang kepiting bakau inilah yang akan diolah menjadi kitosan.

\section{Pembuatan Kitosan}

Isolasi kitin dari cangkang kepiting bakau dilakukan dengan menggunakan metode yang dikembangkan oleh No dan Meyers, 1997. Tahap deproteinasi menggunakan $\mathrm{NaOH} 3,5 \% 1: 2$ (b:v) dan dipanaskan pada suhu $70^{\circ} \mathrm{C}$ selama 2 jam. Selanjutnya campuran ini didinginkan dan disaring, residu yang tersaring dicuci dengan aquades sampai netral dikeringkan dalam oven dengan suhu $60^{\circ} \mathrm{C}$ selama 24 jam. Tahap demineralisasi menggunakan larutan $\mathrm{HCl}$ 15\% 1:2 (b:v) dan dipanaskan pada suhu $30^{\circ} \mathrm{C}$ selama 1 jam. Hasil reaksi disaring dan dicuci dengan aquades sampai netral, selanjutnya dikeringkan dalam oven dengan suhu $80^{\circ} \mathrm{C}$ selama 24 jam. Tahap deasetilasi, kitin hasil isolasi selanjutnya dihilangkan gugus asetilnya dengan larutan $\mathrm{NaOH} 60 \% 1: 2$ (b:v) dan dipanaskan pada suhu $70^{\circ} \mathrm{C}$ selama 2 jam. Hasilnya disaring dan dicuci dengan aquades sampai netral. Kitosan dikeringkan dalam ovendengan suhu $80^{\circ} \mathrm{C}$ selama 24 jam.

\section{Karakterisasi Kitosan}

Kadar air kitosan ditentukan dengan mengetahui selisih berat dari cawan berisi sampel kitosan dengan berat tertentu. Sebelum dan setelah cawan berisi sampel sebanyak $10 \mathrm{mg}$ dimasukkan ke dalam oven pada suhu $100^{\circ} \mathrm{C}$ selama satu jam. Sebelum penimbangan awal dan dimasukkan ke dalam oven, cawan terlebih dahulu dimasukkan ke desikator. Demikian juga setelah dipanaskan dalam oven, cawan dimasukkan ke dalam desikator baru kemudian ditimbang. 
Penyimpanan dalam desikator bertujuan untuk menyeimbangkan kelembaban yang ada di dalam sampel.

Penentuan derajat deasetilasi kitosan yang diperoleh kemudian dikarakterisasi dengan analisis spektofotometri FTIR mengacu pada metode Sabnis dan Block, 1997. Sebanyak $1 \mathrm{mg}$ kitosan yang sudah diblender sampai halus dicampur dengan $\mathrm{KBr} 1 \% \mathrm{~b} / \mathrm{b}$. Campuran ini kemudian ditekan sehingga berbentuk pelet. Pelet $\mathrm{KBr}$ yang diperoleh dimasukkan ke tempat cuplikan dan direkan spectrum serapan infra merahnya pada bilangan gelombang $4000-650 \mathrm{~cm}^{-}$ 1 .

Derajat deasetilasi dihitung dengan memberikan sinar infra merah pada sampel kitosan kemudian serapan infra merah direkam. Gugus hidroksil berada pada panjang gelombang $1655 \mathrm{~cm}^{-1}$ sedangkan gugus amida berada pada panjang gelombang $3450 \mathrm{~cm}^{-1}$. Perhitungan derajat deasetilasi kitosan dapat dihitung dengan menggunakan persamaan (1) di bawah ini.

$\% \mathrm{DD}=\left[1-\left(\frac{A 1655}{A 3450} \times \frac{1}{1,33}\right)\right] \times 100 \%$

dimana:

$\mathrm{A}_{1655}=$ absorbansi kitosan pada panjang gelombang $1655 \mathrm{~cm}^{-1}$

$\mathrm{A}_{3450}=$ absorbansi kitosan pada panjang gelombang $3450 \mathrm{~cm}^{-1}$

\section{Aplikasi Kitosan sebagai Adsorben}

Proses penjernihan air yang dapat dilakukan adalah proses adsorbsi (penyerapan). Dalam hal ini adsorben yang aman digunakan adalah adsorben yang berasal dari senyawa alam yaitu kitosan. Kitosan sebagai adsorben dapat menurunkan kekeruhan dan menurunkan partikel anorganik maupun organik yang tersuspensi dalam air. Penelitian ini dilakukan dengan menggunakan kitosan sebagai adsorben air sumur dengan menganalisis kekeruhan dan $\mathrm{pH}$ dengan variasi waktu dan variabel yang berbeda dalam $60 \mathrm{ml}$ sampel air sumur

\section{HASIL DAN PEMBAHASAN}

Kitosan yang diisolasi dari cangkang kepiting bakau dapat digunakan sebagai adsorben, sebagai adsorbat dipilih. Gugus - NH2 mempunyai sepasang elektron bebas, itu berarti mempunyai sifat basa, atau dalam larutan (air) akan meningkatkan pH sistem.

Penentuan kadar air memperlihatkan jumlah kandungan air dalam kitosan. Kadar air yang terkandung di dalam serbuk kitosan dinyatakan sebagai $\mathrm{H}_{2} \mathrm{O}$ yang terikat pada gugus-gugus fungsional polimer kitosan, terutama gugus amina, $\mathrm{N}$ asetil, dan hidroksil melalui ikatan hidrogen. Kadar air dalam kitosan pada penelitian ini diketahui sebesar $3,46 \%$ dan kadar abu yang diperoleh sebesar $1,00 \%$.

Deasetilasi kitin dilakukan dengan menghilangkan gugus asetil yang berikatan dengan gugus amina menggunakan $\mathrm{NaOH}$ pekat agar ikatan $\mathrm{C}-\mathrm{N}$ gugus 
asetamida pada atom C-2 pada asetamida kitin dapat terputus, sehingga terbentuk gugusamina (-NH2) pada kitosan. Perubahan kitin menjadi kitosan merupakan reaksi hidrolisa, banyaknya gugus asetil yang hilang pada proses deasetilasi menunjukkan besarnya (\%) deasetilasi kitosan.

\section{Karakterisasi Kitosan}

Kitosan yang dihasilkan dari ekstraksi cangkang kepiting bakau diperoleh sebanyak $30 \mathrm{gr}$ berbentuk serbuk dan berwarna putih serta tidak berbau. Hasil serapan FTIR memperlihatkan serapan yang beragam dari gugus-gugus fungsi yang dimiliki kitosan dari cangkang kepiting bakau diperlihatkan pada Gambar 1 .

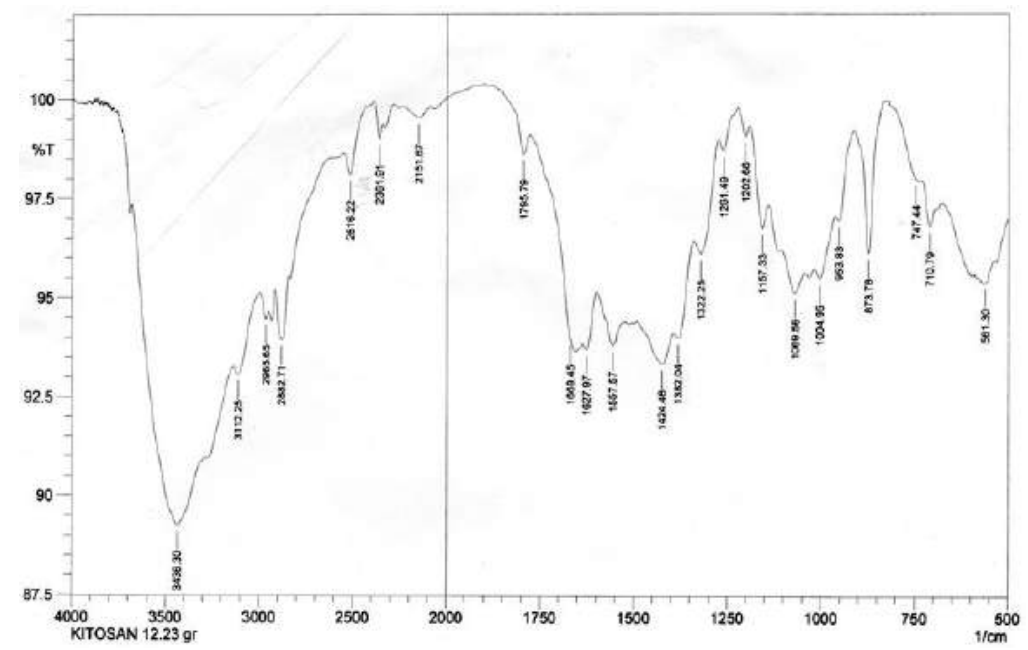

Gambar 1. Spektrum FTIR Kitosan Cangkang Kepiting Bakau

Dari hasil FTIR tersebut diperoleh jenis gugus-gugus fungsi pada kitosan cangkang kepiting bakau yang dapat dilihat pada tabel 1 .

Tabel 1. Jenis Gugus- Gugus Fungsi pada Kitosan

\begin{tabular}{|c|c|c|}
\hline Daerah Frekuensi $\mathbf{( c m}^{-1} \mathbf{)}$ & Ikatan & Tipe Senyawa \\
\hline $3300-3500$ & $\mathrm{~N}-\mathrm{H}$ & Amina, Amida \\
\hline $3200-3600$ & $\mathrm{O}-\mathrm{H}$ & Hidroksil \\
\hline 2927.03 & $\mathrm{C}-\mathrm{H}$ & Alkana \\
\hline 2521.97 & $\mathrm{O}-\mathrm{H}$ & Hidroksil \\
\hline 1466.89 & $\mathrm{C}-\mathrm{H}$ & Alkana \\
\hline 1083.05 & $\mathrm{C}-\mathrm{O}$ & Asam Karboksilat \\
\hline 862.20 & $\mathrm{C}-\mathrm{H}$ & Alkena \\
\hline
\end{tabular}

Derajat Deasetilasi (DD) kitosan diperoleh sebesar 73\%. Sehingga dari nilai DD tersebut diketahui bahwa kitosan dapat digunakan sebagai adsorben. Sebagaimana dalam penelitian sebelumnya oleh Muzarelli, (1977) bahwa semakin 
tinggi DD maka semakin murni kitosan tersebut dan semakin baik untuk diaplikasikan sebagai adsorben. Gugus hidroksil dan amida menjadi titik yang sangat perlu diperhatikan karena kedua gugus tersebut mempunyai peranan penting sebagai adsorben penjernih.

\section{Kitosan Sebagai Adsorben}

\section{Analisis Kadar pH}

Analisa kadar $\mathrm{pH}$ pada sampel sumur setelah penambahan kitosan sangat penting, untuk mengetahui apakah sampel air tersebut sudah masuk kedalam standar air jernih atau belum. Oleh katena itu, kadar $\mathrm{pH}$ pada sampel air dapat menujukkan apakah kitosan dapat bekerja secara efektif sebagai adsroben untuk melakukan proses penjernihan air, yaitu $\mathrm{pH}$ yang sesuai dengan standar air jernih berada diantara 6.5-8.5.

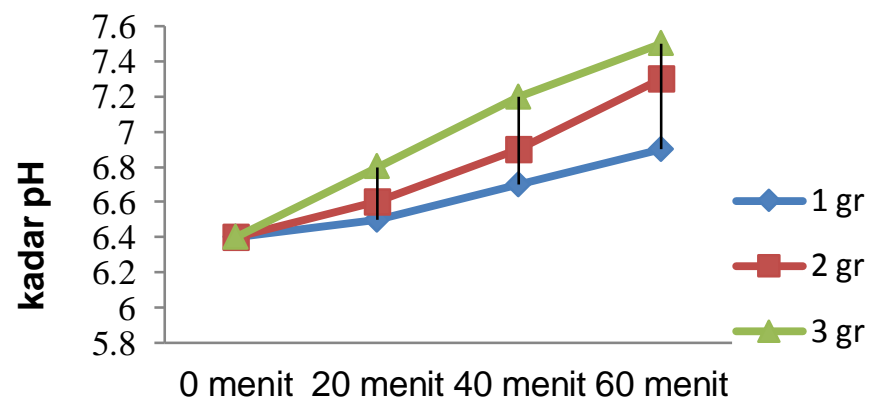

Waktu

Gambar 2. Grafik Hubungan antara Kadar pH terhadap Waktu Kontak Kitosan pada Air Sumur

\section{Analisis Kekeruhan}

Pengujian parameter kekeruhan pada air sumur ini bertujuan untuk mengetahui seberapa keruh air yang akan diuji atau menentukan kejernihan pada air sumur. Kekeruhan pada air dapat disebabkan oleh partikel-partikel tanah liat, lempung, lanau atau akibat buangan limbah rumah tangga maupun limbah industri. Standar nilai kekeruhan air sumur yaitu tidak lebih dari 5 NTU. 


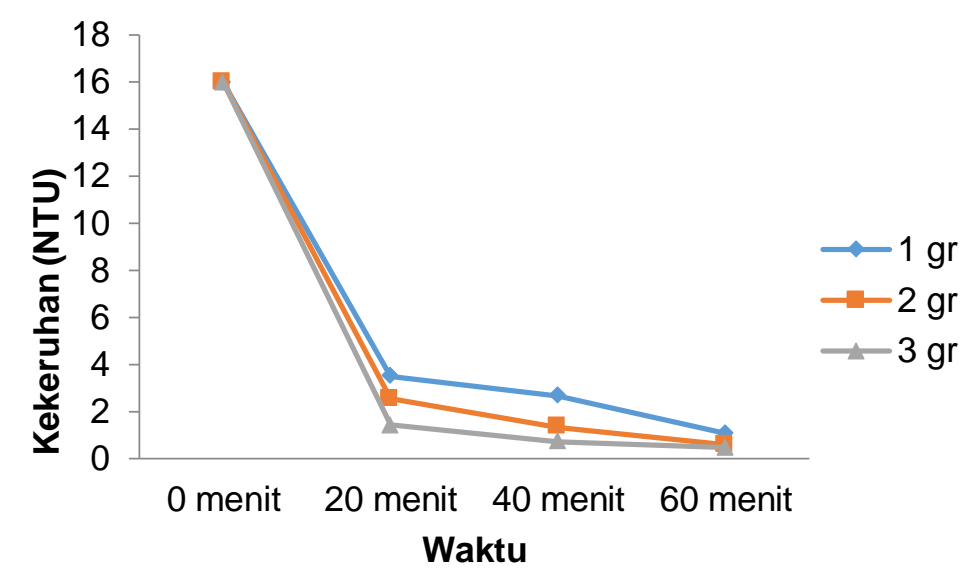

Gambar 3. Hubungan antara Kekeruhan terhadap Waktu Kontak Kitosan pada Air Sumur

Pada Gambar 2 dan Gambar 3 dapat dilihat bahwa kadar $\mathrm{pH}$ dan kekeruhan sangat berpengaruh pada waktu. Grafik analisis kadar pH menunjukkan bahwa semakin lama waktu yang digunakan semakin tinggi kadar $\mathrm{pH}$ itu terlihat dari tiga variabel (1gr, 1gr, 3gr) yang dianalisis. Sedangkan pada grafik analisis kekeruhan menunjukkan adanya penurunan nilai kekeruhan pada air sumur. Penurunan nilai kekeruhan diduga karena kitosan yang digunakan sebagai adsorben mampu mengikat pengotor yang terdapat pada air sumur. Hasilnya, bau air sumur menjadi tidak berbau dan untuk warna air sumur menjadi tidak berwarna atau jernih.

\section{KESIMPULAN}

Cangkang kepiting bakau telah diisolasi kitinnya dan berhasil disintesis menjadi kitosan sesuai dengan hasil karakterisasi kitosan yaitu memiliki tekstur serbuk bewarna putih kekuningan, tidak berbau, memiliki kadar air 3,46\%, kadar abu $1 \%$, dan derajat deasetilasi sebesar $73 \%$. Kitosan tersebut dapat digunakan sebagai adsorben penjernih air sumur. Hasilnya, bau air sumur menjadi tidak berbau dan untuk warna air sumur menjadi tidak berwarna atau jernih. Air sumur setelah ditambahan kitosan mengalami kenaikan pada nilai $\mathrm{pH}$ dan penurunan nilai kekeruhan. Semakin tinggi dosis kitosan yang ditambahkan ke dalam sampel air sumur, maka semakin mendekati baku mutu air jernih, begitu juga dengan penambahan waktu kontak. 


\section{DAFTAR PUSTAKA}

Anonim, 1990, Peraturan Pemerintah No. 20 Tahun 1990 tentang Pengendalian Pencemaran Air.

AOAC, 1995. Official Methods of Analysis of Assocition of Official Analitycal Chemists. Associttion of Official Analitycal Chemist, Washington DC.

Bastaman, S, Aprianita, Hendarti, 1990, Penelitian Limbah Udang sebagai Bahan Industri Khitin dan Khitosan, Balai Besar penelitian dan Pengembangan Industri Hasil Pertanian, Jakarta.

Brzeski, M.M., 1987. Chitin and Chitosan Putting Waste to Good Use, Info Fish International (5). P.31-33.

Endoraza Nuralam, Bella Pratiwi Arbi, Prasetyowati. 2012. Pemanfaatan Limbah Cangkang Kepiting menjadi Kitosan sebagai Penjernih Air pada Air Sumur. Desember 2012, Jurnal Teknik Kimia Fakultas Teknik Universitas Sriwijaya No. 4, Vol. 18.

Fernandez-Kim, S.-O., 2004, Physicochemical and Functional Properties of Crawfish Chitosan as Affected by Different Processing Proto-cols, A Thesis in Department of Food Science, Seoul National University.

Harianingsih. 2010. Pemanfaatan Limbah Cangkang Kepiting Menjadi Kitosan sebagai Bahan Pelapis (Coater) pada Buah Stroberi, Laporan Tesis, Program Magister Teknik Kimia.Universitas Diponegoro.

Masduki. 1996. Mempelajari Efektivitas Kitosan Dari Limbah Udang Untuk Penjernihan Air Sungai [Skripsi]. Bogor: Program Studi Teknologi Hasil Perikanan, Fakultas Perikanan dan IImu Kelautan, Institut Pertanian Bogor.

Moosa, M.K., I. Aswandy dan A. Karsy. 1985. Kepiting Bakau-Scylla Serrata (Forskal) Dari Perairan Indonesia. LON-LIPI. Jakarta

Muzzarelli, R.A.A., (1977), "Chitin in the Polysaccharides", vol. 3, pp. 147, Aspinall (ed) Academic press Inc., Orlando, San Diego

Peraturan Menteri Kesehatan RI No. 173/Menkes/VII/77. Tentang Penyediaan Air Minum yang Harus Memenuhi Standar Kuantitas dan Kualitas. Jakarta.

Riyadi, Slamet. 1984. Pencemaran Air, Seri Lingkungan Dasar-dasar dan PokokPokok Penanggulangan. Surabaya: Karya Anda.

Roberts, G.A.F. 1997. Chitin Chemistry. The Macmillan Press Ltd, London. 
Said, N. I., 1999. Pengolahan Air Siap Minum. Jurnal Teknologi Pengolahan Air Minum. Direktorat Teknologi Lingkungan, Deputi Bidang Teknologi Informasi, Energi, Material dan Lingkungan-Badan Pengkajian dan Penerapan Teknologi. Jakarta.

Sinardi, Soewondo prayatni, Notodarmojo Suprihanto. 2013. Pembuatan Karakterisasi dan Aplikasi Kitosan dari Cangkang Kerang Hijau (Mytulus Virdis Linneaus) Sebagai Koagulan Penjernih Air. KoNTekS 7. 24-26 Oktober 2013, Kampus Universitas Sebelas Maret (UNS).

Sukmawati. 2014. Pemanfaatan Limbah Kulit Udang Menjadi Kitosan Sebagai Pengawet Alami [Skripsi].Makassar: Program Studi Teknik Kimia Fakultas Teknik Universitas Fajar Makassar.

Suptijah P. 2006. Deskriptif Karaktaristik dan Aplikasi Kitin - Kitosan. Di dalam Prosiding Seminar Nasional Kitin Kitosan. Bogor: Departemen Hasil Perairan. Fakultas Perikanan dan IImu Kelautan. Institut Pertanian Bogor.

Thate MR. 2004. Synthesi and Antibacterial Assessment of Water-Soluble Hydrophobic Chitosan Derivatives Bearing Quaternary Ammonium Functionality. Louisiana: Disertasi

Tokura S, Nishi. 1995. Spesification and Characterization of Chitin ang Chitosan Collection of working Papers.University Kebangsaan of Malaysia. Malaysia 